\title{
DIFFERENCES IN POWER DISTRIBUTION AND HEALTH RISK FOR THE TOOL OPERATOR PREDICTED BY HUMAN PHYSICAL MODELS IN THE ISO 10068:2012 STANDARD
}

\begin{abstract}
The article presents an approach to assessing human physical models specified in the ISO 10068:2012 standard. The models were compared on the basis of energy analysis, which was conducted in terms of power distribution. Since the models in question have a fully specified internal structure, the investigation focused on power distribution in the models and the total power in the system. The article provides a description of the construction and energy-based modelling of Human-Tool systems. Simulation results obtained during the study were analysed in terms of health risks posed to the tool operator.
\end{abstract}

\section{Introduction}

Research focused on developing human models using discrete models was conducted as early as 1970s. Major contributions in this field were made by Reynolds [1], Meltzer [2], Suggs [3] and Griffin [4]. The impact of vibrations on the human body was later analysed with other models, which differed in the number of degrees of freedom, the number of components of the dynamic structure and ways in which they were connected [5-7].

New models were always meant to provide a better representation of how the human body reacts to mechanical vibrations, and, thus, undermined the adequacy of previous models. As a result, the problem of choosing an appropriate model became increasingly difficult as the number of available models increased. This situation gave rise to a wave of new studies aimed at compar-

* Institute of Applied Mechanics, Faculty of Mechanical Engineering and Management, Poznan University of Technology, Poland; e-mail: marian.dobry@put.poznan.pl, tomasz. hermann@put.poznan.pl 
ing different models [7] or investigating the effect of excitations on the system response [8].

In general, various models were compared in terms of specific functions of impedance and graphs showing changes in the phase angle [7,8]. It should be noted that the main focus was on the response generated by the model, which should be as close as possible to the result obtained for a real system. Moreover, if that was the case, one should also account for the internal structure of the model. If a given model is to be fully compatible with the real system, it should possess accurately specified response characteristics and at least adequately defined internal structure. This fact is all the more interesting when one considers the withdrawal of the ISO 10068:1998 standard [9] in 2012 and the fact that models specified in the standard had been used for many years all over the world. Work on new models from ISO 10068:2012 had been carried out for a number of years and had been presented in numerous articles [10-12].

This article presents an approach to comparing two physical models for the Human-Tool system, which were constructed using human physical models specified in the ISO 10068:2012 [13]. The main criterion for model assessment was the similarity of energy phenomena observed in the dynamic structures in the process of operation. The energy-based comparison of the physical models of the systems was conducted in terms of power inputs: which were calculated to account for three types of powers and the total power.

\section{Energy models of human-tool systems}

Two human biomechanical models specified in the new ISO 10068:2012 [13] standard were analysed. The two models of interest are discrete models, in which respective points of reduction are connected by means of spring and damping systems. Basic parameters of these models are specified in the ISO 10068:2012 standard [13] - Table 1 and 2.

Table 1.

Values of dynamic parameters for model 1 from the ISO 10068:2012 standard - annex B [13]

\begin{tabular}{|c|c|c|c|c|}
\hline \multirow{2}{*}{ Parameter } & \multirow{2}{*}{ Unit } & \multicolumn{3}{|c|}{ Vibration direction } \\
\cline { 3 - 5 } & & $x$ & $y$ & $\boldsymbol{z}$ \\
\hline$m_{1}$ & $\mathrm{~kg}$ & 0.5479 & 0.5374 & $\mathbf{1 . 2 4 5 8}$ \\
\hline$m_{2}$ & $\mathrm{~kg}$ & 0.0391 & 0.0100 & $\mathbf{0 . 0 7 4 2}$ \\
\hline$k_{1}$ & $\mathrm{~N} / \mathrm{m}$ & 400 & 400 & $\mathbf{1 0 0 0}$ \\
\hline$k_{2}$ & $\mathrm{~N} / \mathrm{m}$ & 0 & 17648 & $\mathbf{5 0 0 0 0}$ \\
\hline$c_{1}$ & $\mathrm{~N} \cdot \mathrm{s} / \mathrm{m}$ & 22.5 & 38.3 & $\mathbf{1 0 8 . 1}$ \\
\hline$c_{2}$ & $\mathrm{~N} \cdot \mathrm{s} / \mathrm{m}$ & 202.6 & 75.5 & $\mathbf{1 4 2 . 4}$ \\
\hline
\end{tabular}


Table 2.

Values of dynamic parameters for model 2 from the ISO 10068:2012 standard - annex C [13]

\begin{tabular}{|c|c|c|c|c|}
\hline \multirow{2}{*}{ Parameter } & \multirow{2}{*}{ Unit } & \multicolumn{3}{|c|}{ Vibration direction } \\
\cline { 3 - 5 } & & $x$ & $y$ & $\boldsymbol{z}$ \\
\hline$m_{1}$ & $\mathrm{~kg}$ & 0.4129 & 0.7600 & $\mathbf{1 . 1 2 5 2}$ \\
\hline$m_{2}$ & $\mathrm{~kg}$ & 0.0736 & 0.0521 & $\mathbf{0 . 0 7 6 9}$ \\
\hline$m_{3}$ & $\mathrm{~kg}$ & 0.0163 & 0.0060 & $\mathbf{0 . 0 2 0 0}$ \\
\hline$m_{4}$ & $\mathrm{~kg}$ & 0.0100 & 0.0028 & $\mathbf{0 . 0 1 0 0}$ \\
\hline$k_{1}$ & $\mathrm{~N} / \mathrm{m}$ & 400 & 500 & $\mathbf{1 0 0 0}$ \\
\hline$k_{2}$ & $\mathrm{~N} / \mathrm{m}$ & 200 & 100 & $\mathbf{1 2 0 0 0}$ \\
\hline$k_{3}$ & $\mathrm{~N} / \mathrm{m}$ & 4000 & 4907 & $\mathbf{4 3 6 3 5}$ \\
\hline$k_{4}$ & $\mathrm{~N} / \mathrm{m}$ & 8000 & 17943 & $\mathbf{1 7 4 5 4 2}$ \\
\hline$c_{1}$ & $\mathrm{~N} \cdot \mathrm{s} / \mathrm{m}$ & 20.0 & 28.1 & $\mathbf{1 1 1 . 5}$ \\
\hline$c_{2}$ & $\mathrm{~N} \cdot \mathrm{s} / \mathrm{m}$ & 100 & 39.7 & $\mathbf{3 9 . 3}$ \\
\hline$c_{3}$ & $\mathrm{~N} \cdot \mathrm{s} / \mathrm{m}$ & 144.6 & 50.7 & $\mathbf{8 6 . 8}$ \\
\hline$c_{4}$ & $\mathrm{~N} \cdot \mathrm{s} / \mathrm{m}$ & 79.9 & 14.3 & $\mathbf{1 2 1 . 0}$ \\
\hline
\end{tabular}

A comparative assessment of the models required the construction of physical models of a Human-Tool system. The human models specified in the ISO 10068:2012 standard [13] were used for this purpose - model 1 (annex B) and model 2 (annex C). Models of Human-Tool systems shown in Fig. 1 are the result of combining physical models in the ISO standard [13] with a model of a power tool. In this particular case the tool model was limited to one mass $m_{N}$ of $15 \mathrm{~kg}$ and the driving force $\mathrm{F}(\mathrm{t})$ producing vibrations.

a)

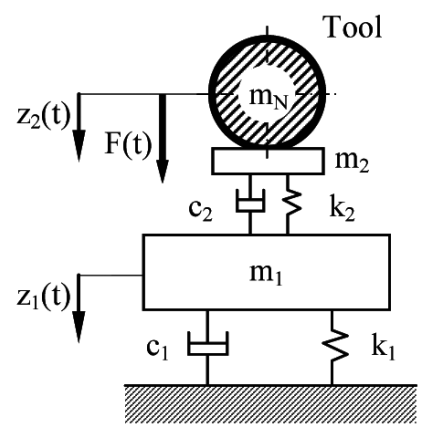

b)

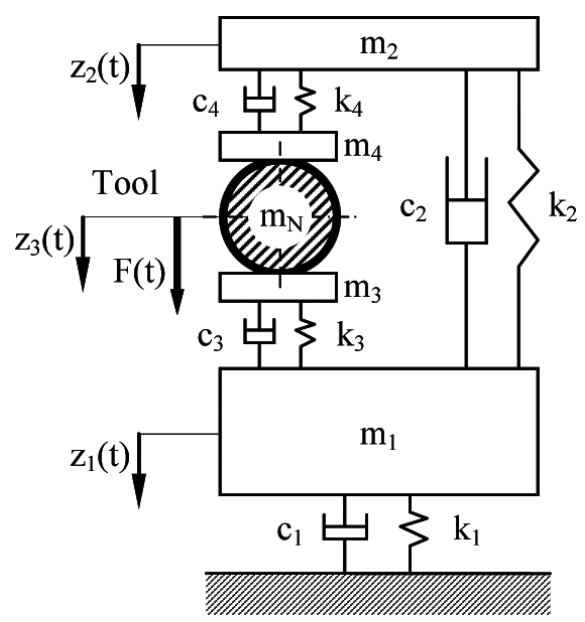

Fig. 1. A synthesis of the ISO 10068:2012-based human physical models and the tool model: a) model 1 - annex B; b) model 2 - annex C [13] 
Both models made it possible to model the impact of vibrations on the human body for three vibration directions $-x, y$ and $z$ (Table 1 and 2). The number of directions taken into account determines the number of differential equations of motion that need to be formulated. A complete analysis of the impact of vibrations on the human body requires the following:

a) with respect to the model with two points of reduction, 6 generalized coordinates need to be specified and 6 differential equations of motion need to be formulated, since the model has two points of reduction and 6 degrees of freedom,

b) with respect to the model with three points of reduction, 9 generalized coordinates need to be specified and 9 differential equations of motion need to be formulated, since the model has three points of reduction and 9 degrees of freedom.

In the study, the energy-based assessment was conducted for a simplified case, whereby the dynamic analysis accounted for only one, main direction of vibrations - along the " $z$ " axis, which is the most significant one in tests of many tools. For the model from ISO 10068:2012 - model 1 [13], the following generalized coordinates were selected (Fig. 1a):

$j=1, \quad q_{1}=z_{1}(t)-$ displacement of mass $m_{1}$,

$j=2, \quad q_{2}=z_{2}(t)-$ displacement of mass $m_{2}$ and $m_{N}$,

where: $m_{N} \quad-$ the mass of the power tool.

In the case of the combined model consisting of the model ISO 10068:2012 - model 2 [13] and the tool model (Fig. 1b), the following generalized coordinates were selected:

$j=1, \quad q_{1}=z_{1}(t)-$ displacement of mass $m_{1}$,

$j=2, \quad q_{2}=z_{2}(t)-$ displacement of mass $m_{2}$,

$j=3, \quad q_{3}=z_{3}(t)-$ displacement of mass $m_{3}, m_{4}$ and $m_{N}$.

After selecting the generalized coordinates, mathematical models of HumanTool systems were formulated. In the case of the Human-Tool system (ISO 10068:2012 - model 1 [13]) the mathematical model has the following form - Fig. 1a:

$j=1, \quad m_{1} \ddot{z}_{1}+\left(c_{1}+c_{2}\right) \dot{z}_{1}+\left(k_{1}+k_{2}\right) z_{1}-c_{2} \dot{z}_{2}-k_{2} z_{2}=0 ;$

$j=2, \quad\left(m_{2}+m_{N}\right) \ddot{z}_{2}+c_{2} \dot{z}_{2}+k_{2} z_{2}-c_{2} \dot{z}_{1}-k_{2} z_{1}=F(t)$.

The mathematical model for the combined model consisting of the ISO 10068:2012 model - model 2 [20] and the tool model - Fig. 1b, is given by: 


$$
\begin{gathered}
j=1, \quad m_{1} \ddot{z}_{1}+\left(c_{1}+c_{2}+c_{3}\right) \dot{z}_{1}+\left(k_{1}+k_{2}+k_{3}\right) z_{1}-c_{3} \dot{z}_{3}-k_{3} z_{3}- \\
-c_{2} \dot{z}_{2}-k_{2} z_{2}=0 ; \\
j=2, \quad m_{2} \ddot{z}_{2}+\left(c_{2}+c_{4}\right) \dot{z}_{2}+\left(k_{2}+k_{4}\right) z_{2}-c_{2} \dot{z}_{1}-k_{2} z_{1}-c_{4} \dot{z}_{3}- \\
-k_{4} z_{3}=0 \\
j=3, \quad\left(m_{3}+m_{4}+m_{N}\right) \ddot{z}_{3}+\left(c_{3}+c_{4}\right) \dot{z}_{3}+\left(k_{3}+k_{4}\right) z_{3}-c_{4} \dot{z}_{2}-k_{4} z_{2}- \\
-c_{3} \dot{z}_{1}-k_{3} z_{1}=F(t) .
\end{gathered}
$$

The differential equations of motion (1) and (2) presented above were used to derive energy models of the Human-Tool systems of interest. By applying the First Principle of Power Distribution in a Mechanical System [5, 14, 15] one can move from a conventional dynamic analysis in the amplitude domain of kinematic quantities to an energetic analysis in the domain of power distribution. Hence, the energy model of the Human-Tool system, based on the model with two points of reduction specified in the ISO 10068:2012 standard can be formulated as follows:

$$
\begin{aligned}
& j=1, \quad m_{1} \ddot{z}_{1} \dot{z}_{1}+\left(c_{1}+c_{2}\right) \dot{z}_{1}^{2}+\left(k_{1}+k_{2}\right) z_{1} \dot{z}_{1}-c_{2} \dot{z}_{2} \dot{z}_{1}-k_{2} z_{2} \dot{z}_{1}=0 ; \\
& j=2, \quad\left(m_{2}+m_{N}\right) \ddot{z}_{2} \dot{z}_{2}+c_{2} \dot{z}_{2}^{2}+k_{2} z_{2} \dot{z}_{2}-c_{2} \dot{z}_{1} \dot{z}_{2}-k_{2} z_{1} \dot{z}_{2}=F(t) \dot{z}_{2} .
\end{aligned}
$$

The energy model for the second Human-Tool system - Fig. 1b, is given by:

$$
\begin{gathered}
j=1, \quad m_{1} \ddot{z}_{1} \dot{z}_{1}+\left(c_{1}+c_{2}+c_{3}\right) \dot{z}_{1}^{2}+\left(k_{1}+k_{2}+k_{3}\right) z_{1} \dot{z}_{1}-c_{3} \dot{z}_{3} \dot{z}_{1}-k_{3} z_{3} \dot{z}_{1}- \\
-c_{2} \dot{z}_{2} \dot{z}_{1}-k_{2} z_{2} \dot{z}_{1}=0 ; \\
j=2, \quad m_{2} \ddot{z}_{2} \dot{z}_{2}+\left(c_{2}+c_{4}\right) \dot{z}_{2}^{2}+\left(k_{2}+k_{4}\right) z_{2} \dot{z}_{2}-c_{2} \dot{z}_{1} \dot{z}_{2}-k_{2} z_{1} \dot{z}_{2}- \\
-c_{4} \dot{z}_{3} \dot{z}_{2}-k_{4} z_{3} \dot{z}_{2}=0 ; \\
j=3, \quad\left(m_{3}+m_{4}+m_{N}\right) \ddot{z}_{3} \dot{z}_{3}+\left(c_{3}+c_{4}\right) \dot{z}_{3}^{2}+\left(k_{3}+k_{4}\right) z_{3} \dot{z}_{3}-c_{4} \dot{z}_{2} \dot{z}_{3}- \\
-k_{4} z_{2} \dot{z}_{3}-c_{3} \dot{z}_{1} \dot{z}_{3}-k_{3} z_{1} \dot{z}_{3}=F(t) \dot{z}_{3} .
\end{gathered}
$$

The above energy models are described by equations of power. Energy models of Human-Tool systems were implemented in MATLAB/Simulink software to calculate timelines of the power of inertia, dissipation and elasticity. The resulting values were used as criteria for the verification of the models under analysis. The models would be regarded as similar if the power distribution observed in their dynamic structures during the tool operation was found to be the same. 


\section{Energy-based calculations in human-tool systems}

Energy-based analysis was conducted for two kinds of mechanical inputs acting on the Human-Tool systems. The first one was a modelled real impulsive signal [16], which is generated by a demolition hammer operating at a frequency of $20 \mathrm{~Hz}$. Figure 2 shows a timeline of impulsive forces generated by a demolition hammer with mass $m_{N}=15 \mathrm{~kg}$.

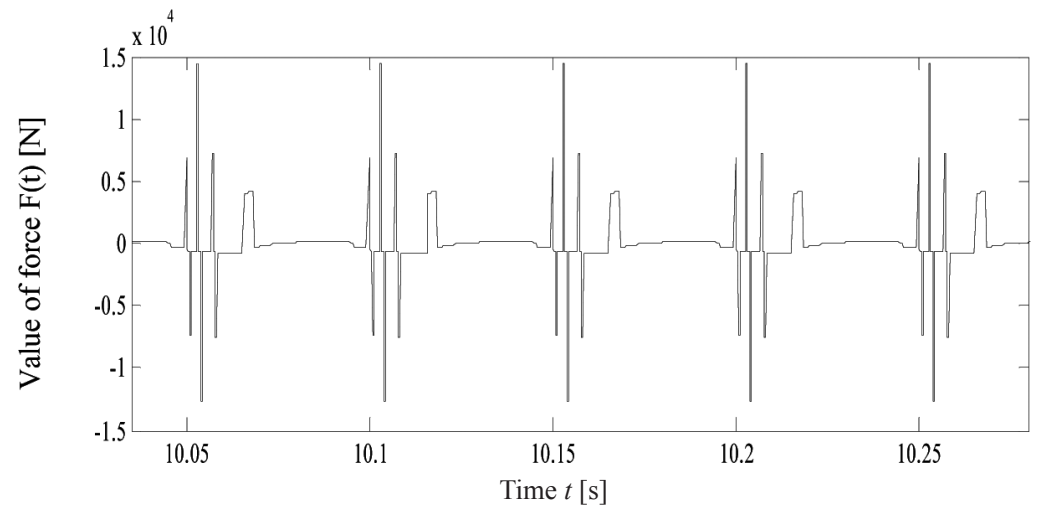

Fig. 2. A timeline of impulsive forces inducing the movement of the Human-Tool system

The model assessment was also conducted for a sinusoidally varying force signal, which is typically generated by an angle grinder employing the frontal area of the disc. Given the known RMS value of vibration acceleration $a_{\mathrm{RMS}}=150 \mathrm{~m} / \mathrm{s}^{2}$ at the point of direct contact between the human operator and the tool, a matching sinusoidal signal was selected. A similar RMS value of vibration acceleration for the sinusoidal signal was obtained with an amplitude of $3400 \mathrm{~N}$. At this amplitude it was possible to achieve the RMS value of vibration acceleration of $150 \pm 1 \mathrm{~m} / \mathrm{s}^{2}$ at the point of direct contact between the human operator and the tool for all cases. The remaining parameters, i.e. the mass and the frequency of the tool, in this particular analysis remained unchanged $-m_{N}=15 \mathrm{~kg}$ and $f=20 \mathrm{~Hz}$.

Simulations in MATLAB/Simulink were conducted for time $t$ equal to 300 seconds. A further extension of the simulation time by $10 \%$ was not necessary, since the resulting decrease in the average power did not exceed $1 \%$. This means that the expected maximum error of averaging the power value did not exceed $1 \%$. Simulations were implemented using integration time steps ranging from a maximum of 0.0001 to a minimum of 0.00001 second. The integration procedure ode113 (Adams) with a tolerance of 0.001 was used.

By applying the First Principle of Power Distribution in a Mechanical System $[5,14,15]$ it was possible to precisely determine the values of three types of power in each system. The energy model equations (3) and (4) re- 
sulted in timelines of instantaneous power, which needed to be integrated and averaged to obtain the RMS value of power.

For the Human-Tool model based on the model with two points of reduction specified in the ISO 10068:2012 standard - Fig. 1a, different values of power were calculated using the following formulas:

a) the power of inertia expressed in [W]:

$$
P_{2 \mathrm{INE}(\mathrm{RMS})}=\sqrt{\frac{1}{t} \int_{0}^{t}\left[m_{1} \ddot{z}_{1} \dot{z}_{1}\right]^{2} d t}+\sqrt{\frac{1}{t} \int_{0}^{t}\left[\left(m_{2}+m_{N}\right) \ddot{z}_{2} \dot{z}_{2}\right]^{2} d t}
$$

b) the power of dissipation expressed in [W]:

$$
P_{2 \operatorname{DIS}(\mathrm{RMS})}=\sqrt{\frac{1}{t} \int_{0}^{t}\left[\left(c_{1}+c_{2}\right) \dot{z}_{1}^{2}\right]^{2} d t}+\sqrt{\frac{1}{t} \int_{0}^{t}\left[c_{2} \dot{z}_{2}^{2}\right]^{2} d t} ;
$$

c) the power of elasticity expressed in [W]:

$$
P_{2 \mathrm{ELA}(\mathrm{RMS})}=\sqrt{\frac{1}{t} \int_{0}^{t}\left[\left(k_{1}+k_{2}\right) z_{1} \dot{z}_{1}\right]^{2} d t}+\sqrt{\frac{1}{t} \int_{0}^{t}\left[k_{2} z_{2} \dot{z}_{2}\right]^{2} d t} .
$$

In the case of the second Human-Tool system - Fig. 1b, corresponding types of power were calculated as follows:

a) the power of inertia expressed in [W]:

$$
\begin{aligned}
P_{3 \mathrm{INE}(\mathrm{RMS})} & =\sqrt{\frac{1}{t} \int_{0}^{t}\left[m_{1} \ddot{z}_{1} \dot{z}_{1}\right]^{2} d t}+\sqrt{\frac{1}{t} \int_{0}^{t}\left[m_{2} \ddot{z}_{2} \dot{z}_{2}\right]^{2} d t}+ \\
& +\sqrt{\frac{1}{t} \int_{0}^{t}\left[\left(m_{3}+m_{4}+m_{N}\right) \ddot{z}_{3} \dot{z}_{3}\right]^{2} d t}
\end{aligned}
$$

b) the power of dissipation expressed in [W]:

$$
\begin{gathered}
P_{3 \mathrm{DIS}(\mathrm{RMS})}=\sqrt{\frac{1}{t} \int_{0}^{t}\left[\left(c_{1}+c_{2}+c_{3}\right) \dot{z}_{1}^{2}\right]^{2} d t}+\sqrt{\frac{1}{t} \int_{0}^{t}\left[\left(c_{2}+c_{4}\right) \dot{z}_{2}^{2}\right]^{2} d t}+ \\
+\sqrt{\frac{1}{t} \int_{0}^{t}\left[\left(c_{3}+c_{4}\right) \dot{z}_{3}^{2}\right]^{2} d t}
\end{gathered}
$$


c) the power of elasticity expressed in [W]:

$$
\begin{gathered}
P_{3 \mathrm{ELA}(\mathrm{RMS})}=\sqrt{\frac{1}{t} \int_{0}^{t}\left[\left(k_{1}+k_{2}+k_{3}\right) z_{1} \dot{z}_{1}\right]^{2} d t}+\sqrt{\frac{1}{t} \int_{0}^{t}\left[\left(k_{2}+k_{4}\right) z_{2} \dot{z}_{2}\right]^{2} d t}+ \\
+\sqrt{\frac{1}{t} \int_{0}^{t}\left[\left(k_{3}+k_{4}\right) z_{3} \dot{z}_{3}\right]^{2} d t}
\end{gathered}
$$

Table 3 shows the resulting values of three types of power and total power for two types of mechanical signals acting on Human-Tool systems.

Table 3.

Three types of power and total power for the models specified in the ISO 10068:2012 standard

\begin{tabular}{|c|c|c|c|c|c|c|c|c|c|}
\hline \multicolumn{2}{|c|}{ Driving force } & \multicolumn{4}{|c|}{ Impulsive Force } & \multicolumn{4}{|c|}{ Sinusoidal Force } \\
\hline \multirow{2}{*}{\multicolumn{2}{|c|}{$\begin{array}{c}\text { Model } \\
\text { ISO 10068:2012 }\end{array}$}} & \multicolumn{2}{|c|}{$\begin{array}{c}\text { Model } 1 \\
2 \text { points of } \\
\text { reduction }\end{array}$} & \multicolumn{2}{|c|}{$\begin{array}{c}\text { Model } 2 \\
3 \text { points of } \\
\text { reduction }\end{array}$} & \multicolumn{2}{|c|}{$\begin{array}{l}\text { Model } 1 \\
2 \text { points of } \\
\text { reduction }\end{array}$} & \multicolumn{2}{|c|}{$\begin{array}{c}\text { Model } 2 \\
3 \text { points of } \\
\text { reduction }\end{array}$} \\
\hline & & $\mathrm{W}$ & $\%$ & W & $\%$ & $\mathrm{~W}$ & $\%$ & $\mathrm{~W}$ & $\%$ \\
\hline \multicolumn{2}{|c|}{ Frequency $f$} & \multicolumn{4}{|c|}{$20 \mathrm{~Hz}$} & \multicolumn{4}{|c|}{$20 \mathrm{~Hz}$} \\
\hline \multirow{3}{*}{$\begin{array}{c}\text { Average } \\
\text { Power } \\
\text { (RMS) }\end{array}$} & Inertia & 391.5 & 87.90 & 393.2 & 68.63 & 2146 & 53.30 & 2135 & 28.76 \\
\hline & Dissipation & 24.2 & 5.43 & 41.4 & 7.23 & 878 & 21.81 & 1251 & 16.85 \\
\hline & Elasticity & 29.7 & 6.67 & 138.3 & 24.14 & 1002 & 24.89 & 4038 & 54.39 \\
\hline \multicolumn{2}{|c|}{ Total Power } & 445.4 & 100 & 572.9 & 100 & 4026 & 100 & 7424 & 100 \\
\hline
\end{tabular}

[13] in Watt and percentage

\section{A comparison of the systems and health risk for the tool operator}

Figure 3 shows a power increase between the models for three kinds of power and types of driving force. The rate of change was calculated by comparing the values of power obtained for the model with three points of reduction to the values obtained for the model with two points of reduction. The relationship can be expressed by the following formula:

$$
I_{K}=\frac{P_{3 \mathrm{X}(\mathrm{RMS})}}{P_{2 \mathrm{X}(\mathrm{RMS})}} \cdot 100 \%
$$

where:

$P_{3 \mathrm{X}(\mathrm{RMS})}$ - the RMS value of the power of inertia, dissipation and elasticity for the Human-Tool system with three points of reduction - RMS value in [W], $P_{2 \mathrm{X} \text { (RMS) }}$ - the RMS value of the power of inertia, dissipation and elasticity for the Human-Tool system with two points of reduction - RMS value in [W]. 


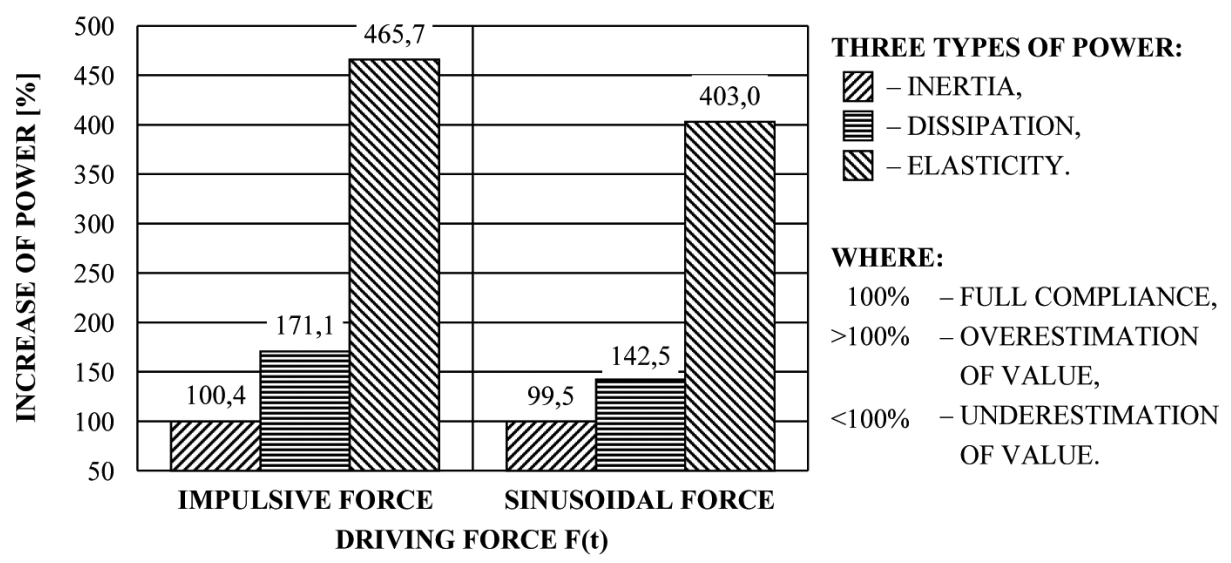

Fig. 3. The effect of the driving force acting on the systems on the increase in the RMS value of three kinds of power

The results presented in Fig. 3 indicate that the values of power calculated for the Human-Tool systems under analysis differ. The highest degree of similarity between the models can be observed in the case of the power of inertia - a difference of up to $0.5 \%$. In the case of the other two kinds of power, much larger discrepancies were observed. A comparison of the power of dissipation revealed a $42.5 \%$ increase for the sinusoidal force and a $71.1 \%$ increase for the impulsive force. An even higher discrepancy was recorded for the power of elasticity, where the percentage increase amounted to $303 \%$ for the sinusoidal force and $366 \%$ for the impulsive force. It is worth noting that the difference between the models in terms of the power of dissipation and elasticity is several dozen percent higher when the Human-Tool systems are affected by the impulsive force than it is in the case of the sinusoidal force. What is more, even assuming the relative error of $30 \%$, it cannot be concluded that the values predicted by the models are similar. In contrast, given the same value of relative error, the values of the power of inertia are comparable.

In Human-Tool systems it is possible to relate the concentration of energy inputs acting on the human body with health risk for the tool operator [14, $15,17]$. There are physiological studies in this area, which confirm this fact [18-20]. One of the outcomes of the study is the analysis of power distribution - Table 3, which can be used to identify the elements of the biological structure that are most severely affected. It turns out that the values of different types of power can be connected with specific effects in the human body:

a) the power of inertia can be linked to blood circulation disorders,

b) the power of dissipation can be linked to an increase in body temperature and adverse effects on nerve tissue,

c) the power of elasticity can be linked to injures to tendons, muscles and joints. 
On the basis of the above correlations it is possible to determine the degree of stress affecting different elements of the biological structure and order the harmful impacts of vibrations on the human body. The order depends on the type of driving force acting on the Human-Tool systems.

A complete qualitative compatibility in the level of energy inputs affecting different elements of the biological structure can be observed for the impulsive force. In this case, the highest energy input is exerted on massive elements, which is related to high levels of acceleration, and hence the power of inertia. This type of energy input is most likely to cause blood circulation disorders. These will be followed by upper limb movement disorders. This is likely to result in injures to tendons, muscles and joints, which is related to the power of elasticity. For both models, the power of dissipation is the smallest contributing factor in the negative impact, which is usually manifested by a rise in body temperature. While the order of negative impacts affecting the biological structure is identical for both models, the percentage contribution of the different types of power is not - Table 3. This means that the resulting disorders which will develop simultaneously in the human body, will be characterised by a different intensity of changes, owing to different contributions of three types of power.

The order of the energy inputs is completely different when the models are affected by the sinusoidal force. In the case of the model with two points of reduction, the analysis of energy inputs revealed that the following order: the highest value of the power of inertia, followed by the power of elasticity and power of dissipation. This indicates that the biggest proportion of the input power generated by the driving force inducing vibrations is used to overcome the system's inertia, then the forces of elasticity, while the smallest part is used to overcome the resistance to motion resulting from the damping forces in the human body. A completely different order of the harmful impact of vibrations on the human body was predicted by the energy analysis for the model with three points of reduction. The following order of energy inputs was observed: the power of elasticity, the power of inertia and dissipation. It is worth noting that when the Human-Tool systems are affected by the sinusoidal force, the contribution of the power of dissipation for both models is the smallest.

Figure 4 shows the increase in total power between models for two kinds of driving force. In this case, the total power is equal to the sum of three kinds of powers. The increase in total power is expressed as a percentage difference of the ratio of the total power observed for the model with three points of reduction to the total power observed for the model with three points of reduction. This dependence is given by:

$$
I_{G}=\frac{P_{3 \mathrm{INE}(\mathrm{RMS})}+P_{3 \mathrm{DIS}(\mathrm{RMS})}+P_{3 \mathrm{ELA}(\mathrm{RMS})}}{P_{2 \mathrm{INE}(\mathrm{RMS})}+P_{2 \mathrm{DIS}(\mathrm{RMS})}+P_{2 \mathrm{ELA}(\mathrm{RMS})}} \cdot 100 \%
$$




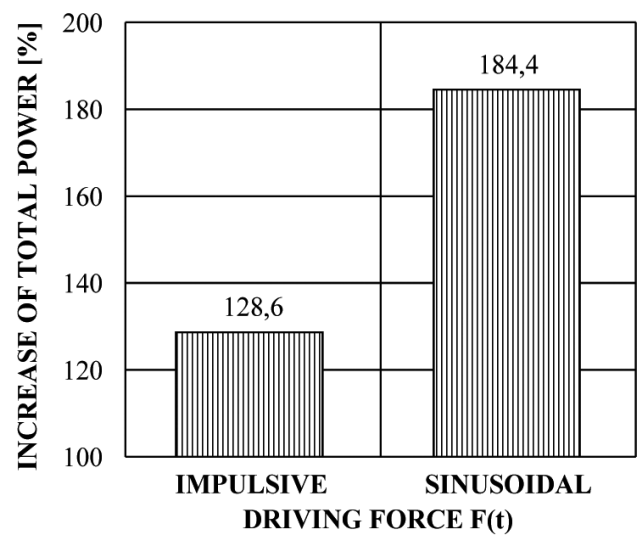

TOTAL POWER

孟 - TOTAL POWER

\section{WHERE:}

$100 \%$ - FULL COMPLIANCE,

$>100 \%$ - OVERSTIMATION

$<100 \% \quad$ OF VALUE,

- UDERSTIMATION

OF VALUE.

Fig. 4. The effect of driving forces affecting the systems on the increase in total power

The results presented in Fig. 4 suggest that the character of the driving forces inducing vibrations in the Human-Tool systems has a major effect on the difference between the models. A comparison of the total power revealed a $28.6 \%$ increase for the impulsive force and an $84.4 \%$ increase for the sinusoidal force.

It is worth pointing out that tools with different characteristics of operation but generating the same RMS value of vibration acceleration $a_{\mathrm{RMS}}$ at the point of direct contact between the human operator and the tool should be assessed differently. This can be explained by the much higher flow of energy through the system when a tool generating a sinusoidal force is used - Table 3. In this case, the human biological structure is exposed to a bigger energy input, which, in turn, results in a much higher intensity of body disorders.

What is more, the model with three points of reduction specified in the ISO 10068:2012 standard - Fig. 1b will predict a consistently higher health risk for the operator of power tools. This is due to the higher flow of energy predicted by the model, which would definitely increase the level of safety requirements that power tools need to meet in order to comply with permissible exposure limit values in an 8-hour working day.

\section{Summary}

The study revealed a discrepancy between the models in terms of power distribution, which was the criterion of model similarity. The simulation results indicated the highest degree of similarity with respect to the power of inertia, with a difference of up to $0.5 \%$. Much higher differences were obtained in the case of the two other kinds of powers, which ranged from $42.5 \%$ to nearly $366 \%$. 
In addition, the study formulated a hierarchy of energy inputs experienced by the human biological structure. The energy analysis revealed a partial similarity between the models in terms of energy input the human biological structure is exposed to. For both models, irrespective of the type of driving force, the negative contribution of the power of dissipation in the Human-Tool systems was the lowest. The values of different types of power were linked to different types of health risk for the human operator.

Another conclusion that can be drawn from the analysis is that the sinusoidal force produces a higher energy input in the Human-Tool systems, which can be measured by the total power of structural forces. It was also demonstrated that the model specified in the ISO 10068:2012 standard with three points of reduction is characterised by a higher total power, which should increase the level of safety requirements concerning vibrations generated on the handles of a working power tool. It is worth noting that the energy-based analysis enables an assessment of health risk for the tool operator working with different tools characterised by different frequencies of operation. This aspect of the problem has been analysed e.g. in [5] and [17].

Finally, it is worth pointing out that the models under analysis display considerable differences in terms of energy inputs. The model comparison indicates that the models' internal structure has a major impact on the health risk for the tool operator. It should be mentioned that the models are characterised by similar maximum values of amplitudes of kinematic quantities - presented in [17]. The difference in the internal structure of the models is due to the discrepancy in energy levels between them. The final verification of the models will be conducted on the basis of energy measurements in the lab. They will provide the data to determine which model structure better represents the energy response of the real system.

\section{Acknowledgments}

The study was partially funded by the Ministry of Science and Higher Education as research project: The flow of energy in mechanical and biomechanical systems 21-431/2013 DS-MK.

Manuscript received by Editorial Board, November 21, 2014; final version, May 23, 2015

\section{REFERENCES}

[1] Reynolds D.D.: Hand-arm vibration: A review of three years' research, Proc. of the 3rd International Hand-Arm Vibration Conference, Ohio, USA, 1977, pp. 99-129.

[2] Meltzer G.: A Vibration Model for the Human Hand-Arm-System. Studies in Environmental Science, 1981, 13, pp. 210-221. 
[3] Suggs C.W.: Modeling of the dynamic characteristic of the hand-arm system. In: W. Taylor and P.L. Pelmear (Eds.), The Vibration Syndrome. Academic Press, London, 1974, pp. 169-186.

[4] Griffin M. J.: Handbook of Human Vibration. Academic Press, London 1990.

[5] Dobry M.W., Hermann T.: A comparison of human physical models used in the ISO 10068:2012 standard based on power distribution - PART 1. Vibrations in Physical Systems, Poznan University of Technology, Poznan, 2014, Vol. 26, pp. 49-56.

[6] Książek A. M.: Analiza istniejących modeli biodynamicznych układu ręka-ramię pod kątem wibroizolacji człowieka - operatora od drgań emitowanych przez narzędzia ręczne (Analysis of the existing biodynamic models of a hand - arm for vibroisolation of human - operator from vibrations emitted by the tool). Czasopismo Techniczne, Wydawnictwo Politechniki Krakowskiej, 1996, z. 2-M, pp. 87-114 (in Polish).

[7] Rakheja S., Wu J. Z., Dong R. G., Schopper A. W.: A comparison of biodynamic models of the Human hand-arm system for applications to hand-held power tools. Journal of Sound and Vibration, 2002, 249(1), pp. 55-82.

[8] Gurram R., Rakheja S., Gouw G. J.: Mechanical impedance of the human hand-arm system subject to sinusoidal and stochastic excitations. International Journal of Industrial Ergonomics, 1995, 16, pp. 135-145.

[9] ISO 10068:1998: Mechanical vibration and shock - Free, mechanical impedance of the human hand-arm system at the driving point.

[10] Dong R. G., Dong J. H., Wu J. Z., Rakheja S.: Modeling of biodynamic responses distributed at the fingers and the palm of the human hand-arm system. Journal of Biomechanics, 2007, 40, pp. 2335-2340.

[11] Dong R. G., Rakheja S., McDowell T. W., Welcome D. E., Wu J. Z.: Estimation of the biodynamic responses distributed at fingers and palm based on the total response of the hand-arm system. International Journal of Industrial Ergonomics, 2010, 40, pp. 425-436.

[12] Dong R. G., Welcome D. E., McDowell T. W., Wu J. Z.: Modeling of the biodynamic responses distributed at the fingers and palm of the hand in three orthogonal directions. Journal of Sound and Vibration, 2013, 332, pp. 1125-1140.

[13] ISO 10068:2012: Mechanical vibration and shock - Mechanical impedance of the human hand-arm system at the driving point.

[14] Dobry M. W.: Optymalizacja przepływu energii w systemie Człowiek-Narzędzie-Podłoże (Optimization of the Energy Flow in the Human - Tool - Base System), Ph.D. Thesis, Poznan University of Technology, Poznan, 1998 (in Polish).

[15] Dobry M. W.: Podstawy diagnostyki energetycznej systemów mechanicznych i biomechanicznych (Fundamentals of Energy Diagnostics of Mechanical and Biomechanical Systems). Wydawnictwo Naukowe Instytutu Technologii Eksploatacji - PIB, Radom 2012 (in Polish).

[16] Wojsznis M.: Dynamika przepływu energii w systemie biomechanicznym: Człowiek - Duże Zmechanizowane Narzędzie Ręczne (The dynamics of energy flow in biomechanical system: Human - Large Mechanized Hand Tool), post-Ph.D. Thesis, Poznan University of Technology, Poznan, 2005 (in Polish).

[17] Dobry M.W., Hermann T.: A comparison of human physical models used in the ISO 10068:2012 standard based on power distribution - PART 2. Vibrations in Physical Systems, Poznan University of Technology, Poznan, 2014, Vol. 26, pp. 57-64.

[18] Marek K.: Choroby zawodowe (Occupational diseases). Wydawnictwo Lekarskie PZWL, Warszawa, 2009 (in Polish).

[19] Markiewicz L.: Fizjologia i higiena pracy. Wibracja (Physiology and Hygiene of Work. Vibration (in Polish)), Instytut Wydawniczy CRZZ, Warszawa, 1980.

[20] Taylor W., Pelmear P. L.: Vibration White Finger in Industry. Academic Press, London - New York - San Francisco, 1973. 
Różnice w rozdziale mocy i zagrożenia dla zdrowia Operatora w przypadku modeli fizycznych Czlowieka z normy ISO 10068:2012

\section{Streszczenie}

W pracy przedstawiono sposób oceny modeli fizycznych człowieka z normy ISO 10068:2012. Modele porównano metodą energetyczną, która w prezentowanym przypadku została zrealizowana w dziedzinie rozdziału mocy. Badane modele posiadają w pełni określoną strukturę wewnętrzną, dlatego zwrócono uwagę na rozdział mocy w tych modelach oraz moc globalną w całym systemie. Przedstawiono proces budowy i modelowania energetycznego systemów Człowiek - Narzędzie. Zaprezentowano również wyniki symulacji oraz powiązano otrzymane wartości z zagrożeniami dla zdrowia człowieka. 